\title{
Pterostilbene Enhances Anticancer Effects of L-asparaginase in Lymphoblastic Leukaemia Cell Line
}

\author{
T. RAHIMNEJAD, P. BESHKAR ${ }^{1}$ R. BAGHERI² AND B. POURGHEYSARI3,4*
}

Immunology Department, Shahrekord University of Medical Sciences, ${ }^{1}$ Cellular and Molecular Research Center, Basic Health Sciences Institute, Shahrekord University of Medical Sciences, Shahrekord, 2 School of Medicine, Tehran University of Medical Sciences, Tehran, ${ }^{3}$ Pathology and Hematology Department, Shahrekord University of Medical Sciences, Shahrekord, ${ }^{4}$ Medical Plant Research Center, Basic Health Sciences Institute, Shahrekord University of Medical Sciences, Shahrekord, Iran

Rahimnejad et al.: Pterostilbene enhances anticancer effects of L-ASP

\begin{abstract}
Antiproliferative and apoptotic effects of pterostilbene were examined in combination with L-asparaginase in Jurkat cell line. Jurkat cells were incubated with different concentrations of pterostilbene alone or in combination with $\mathrm{L}$-asparaginase for 24,48 and $72 \mathrm{~h}$. Cell viability was evaluated using 3-(4,5-dimethylthiazol2-yl)-5-3-carboxymethoxyphenyl)-2-(4-sulfophenyl)-2H-tetrazolium assay. Induction of apoptosis was measured by annexin- $V$ fluorescein isothiocyanate and the level of active caspase 3 positive cells by intracellular staining and flowcytometry. Decline of cell viability to $50 \%$ was observed at $67.78 \pm 3.88$, 60.97 \pm 3.36 and $52.11 \pm 2.50 \mu \mathrm{M}$ concentration after 24,48 and $72 \mathrm{~h}$ incubation with pterostilbene, respectively. Pterostilbene at a concentration of 30,50 and $70 \mu \mathrm{M}$ in combination with 0.5 and $0.7 \mathrm{IU} / \mathrm{ml} \mathrm{L}$-asparaginase reduced relative cell growth to a significant level. The rate of apoptosis was significantly higher than control at $80 \mu \mathrm{M}$ concentration of pterostilbene and a combination of $60 \mu \mathrm{M}$ pterostilbene with 0.5 and $0.7 \mathrm{IU} / \mathrm{ml}$ L-asparaginase, but not with L-asparaginase alone. The level of caspase 3 positive cells was significantly higher than control at $80 \mu \mathrm{M}$ concentration of pterostilbene. Pterostilbene increased antiproliferative and apoptotic effects of L-asparaginase in Jurkat cells. These results suggested that pterostilbene might be a potential anticancer agent in lymphoblastic leukaemia and potentiate the effect of L-asparaginase. Unravelling the mechanism of pterostilbene-induced cell apoptosis in this cell line could help in the development of a targeted therapy.
\end{abstract}

Key words: Pterostilbene, L-asparaginase, Jurkat cell line, proliferation, apoptosis, lymphoblastic leukaemia

Acute lymphoblastic leukaemia (ALL) is the most frequent leukaemia in childhood and almost $25 \%$ of cancer cases under $15 \mathrm{y}$ old ${ }^{[1]}$. The treatment of childhood ALL has developed in the past decade. However common chemotherapy has failed in $20 \%$ of the patients ${ }^{[2]}$. Most therapy failures have been explained by cellular resistance to antileukemia $\operatorname{drugs}^{[3]}$. Children with T-lineage leukaemia are more resistant to a variety of drugs in vitro than B-cell and acute myeloid leukaemia ${ }^{[4]}$.

L-asparaginase (L-ASP) is a well-known and prominent growth inhibitory enzyme in oncology clinics and has been successfully used for combination chemotherapy in ALL and some solid tumours ${ }^{[5]}$. However, this treatment causes anaphylactic reaction and coagulopathy in some patients and may have liver and kidney toxicity. In addition, it is ineffective in some patients ${ }^{[3,6,7]}$. AntiL-ASP has been produced in some patients following treatment, which can cause

*Address for correspondence

E-mail: Bat238@yahoo.com

March-April 2019

Indian Journal of Pharmaceutical Sciences undetectable level of enzyme activity and minimize the effect of the drug ${ }^{[8,9]}$. These limitations point out to looking for alternative or complimentary treatments.

Stilbene-based phytonutrients have attracted the attention of many studies to their wide biological functions. One of such components is resveratrol, which is a phytoalexin found in grapes and some of the other food products and has demonstrated anticancer effects $^{[10]}$. Pterostilbene (PT), the natural analogue of resveratrol with similar pharmacologic properties, is the main antioxidant in blueberries and has been found in several types of grapes and tree wood. PT contains

This is an open access article distributed under the terms of the Creative Commons Attribution-NonCommercial-ShareAlike 3.0 License, which allows others to remix, tweak, and build upon the work non-commercially, as long as the author is credited and the new creations are licensed under the identical terms

Accepted 15 January 2019

Revised 06 May 2018

Received 29 November 2017

Indian J Pharm Sci 2019;81(2):226-233 
two methoxy groups, making it more lipophilic and increasing oral absorption and cellular uptake ${ }^{[11]}$. In oral administration, it showed $95 \%$ bioavailability versus $25 \%$ of resveratrol ${ }^{[12]}$ and its half-life is seven times higher ${ }^{[13]}$. Many studies have demonstrated antiproliferative effects of PT. In association with quercetin, PT inhibited metastasis of B16 melanoma cell line ${ }^{[14]}$. Its anticancer effect has been reported in rodent model ${ }^{[15]}$. Tolomeo and colleagues used different myeloblastic leukaemia including drug resistant cell lines and demonstrated that PT exerted dose-dependent and line-specific inhibitory effect upon cell growth ${ }^{[16]}$. The anticarcinogenic effect of PT has also been demonstrated in bladder, breast, liver, colon, lung, pancreatic and prostatic cell lines ${ }^{[17-23]}$. How it can work in combination with common chemotherapy agents needs to be investigated. The aim of our study was to investigate the antiproliferative, apoptosis and caspase 3 activity of PT versus and in combination with L-ASP in Jurkat cell line as a possible chemotherapy compound.

\section{MATERIALS AND METHODS}

Jurkat cells were purchased from Pasteur Institute (Tehran, Iran). RPMI 1640 medium, penicillin/ streptomycin, trypan blue and PT were obtained from Sigma-Aldrich (Germany). Bovine foetus serum was obtained from GIBCO (USA), apoptosis kit from BD, and caspase 3 assay kit and 3-(4,5-dimethylthiazol-2yl)-5-3-carboxymethoxyphenyl)-2-(4-sulfophenyl)2H-tetrazolium (MTS) from Promega (USA).

\section{Cell culture:}

Jurkat cells were grown in RPMI 1640 supplemented with $0.3 \mathrm{mg} / \mathrm{ml} \mathrm{L}$-glutamine, $10 \%$ fetal calf serum, $100 \mathrm{IU} / \mathrm{ml}$ penicillin and $100 \mu \mathrm{g} / \mathrm{ml}$ streptomycin (complete media) at a concentration of $2 \times 10^{5} / \mathrm{ml}$. The cells were incubated at $37^{\circ}$ in a $5 \% \mathrm{CO}_{2}$ atmosphere.

\section{Cell viability assay:}

To evaluate the number of living and dead cells, the cells were stained with trypan blue and counted on a haemocytometer. Cell viability was assessed by MTS assay in a 96-well plate according to the manufacturer instructions. Briefly, $1 \times 10^{4}$ live cells were seeded per well in above complete media and incubated for $24 \mathrm{~h}$. $10 \mathrm{mg}$ of PT was dissolved in $1 \mathrm{ml}$ dimethyl sulfoxide (DMSO, stock). Working solution was prepared at $400 \mu \mathrm{m}$ in culture media. The cells then were treated with different concentrations of PT $(0-100 \mu \mathrm{m})$, L-ASP (0.01-1 IU/ml) or a combination of them and incubated for 24, 48 and 72 h. $20 \mu l$ of MTS was added to each well and incubated at $37^{\circ}$ in $5 \% \mathrm{CO}_{2}$ for an additional $3 \mathrm{~h}$. The absorbance of the wells was measured against the background (culture medium with DMSO) at $490 \mathrm{~nm}$ (the optical density is proportional to the total number of living cells). At least 3 wells were used for each concentration of the used drugs and values were expressed as mean $\pm \mathrm{SD}$.

\section{Determination of apoptosis and necrosis:}

Cells were seeded in a six well plate with $2 \times 10^{5}$ cells per well in complete media and incubated for $24 \mathrm{~h}$. The cells were then treated with different concentration of PT $(0-100 \mu \mathrm{m})$, L-ASP $(0.01-1 \mathrm{IU} / \mathrm{ml})$ or a combination of them and incubated for 24 and $48 \mathrm{~h}$. The cells were washed twice with PBS after the incubation time and resuspended in binding buffer at a concentration of $10^{6} / \mathrm{ml} .1 \times 10^{5}$ cells were incubated with annexin $\mathrm{V}$ conjugated with fluorescein isothiocyanate (FITC) and propidium iodide (PI) for $20 \mathrm{~min}$. The cells were analysed afterward by flowcytometry (Partec, Germany). Phosphatidyl serine migrates to the outer surface of cell membrane in early apoptosis and bind to annexin V FITC. PI negative and FITC positive cells are in first stage of apoptosis whereas PI and FITC positive cells are in final stage of apoptosis. Both early and final apoptotic cells were recorded as apoptotic cells. The control was treated with highest concentration of DMSO in treated cells for comparison.

\section{Detection of active caspase 3 positive cells:}

The active caspase 3 positive cells were detected using intracellular staining and flowcytometry according to the manufacturer instructions (BD). Briefly, the cells were seeded in a 6 well plate at a concentration of 200000 cells/well in $2 \mathrm{ml}$ media and treated with different concentrations of PT. After $48 \mathrm{~h}$ incubation, the cells were washed and re-suspended in cytofix/ cytoperm and incubated for $20 \mathrm{~min}$ on ice. The cells were then washed with perm/wash buffer and incubated with PE conjugated anticaspase 3 in a perm/wash buffer suspension for $30 \mathrm{~min}$ in darkness at room temperature. The cells were washed and re-suspended in perm/wash buffer and analysed by flowcytometry.

\section{Statistical analysis:}

Values are expressed as the mean $\pm \mathrm{SD}$. All experiments were done at least in triplicate. Data were analysed by SPSS using Kruskal-Wallis multiple comparison and Dunn's test and the difference between control and each experimental condition considered significant if 
$\mathrm{p}$ value was less than 0.05 . EC50 was calculated using probit analysis.

\section{RESULTS AND DISCUSSION}

Cells were incubated with different concentrations of PT. Percent living cells was calculated over a period of 24, 48 and $72 \mathrm{~h}$ and expressed as a percent of the cells incubated with media alone (fig. 1). EC50 was calculated as a drug concentration, which is capable of inhibiting $50 \%$ cell growth. PT displayed an EC50 of $67.78 \pm 3.88 \mu \mathrm{M}$ at $24 \mathrm{~h}, 60.97 \pm 3.36 \mu \mathrm{M}$ at $48 \mathrm{~h}$ and $52.11 \pm 2.50$ at $72 \mathrm{~h}$ of incubation. Cell viability declined to $32.51 \pm 4.93 \%$ and $22.33 \pm 4.72 \%$ at 80 and $100 \mu \mathrm{M}$ concentrations of $\mathrm{PT}$, respectively. The proportion of living cells decreased more over a period

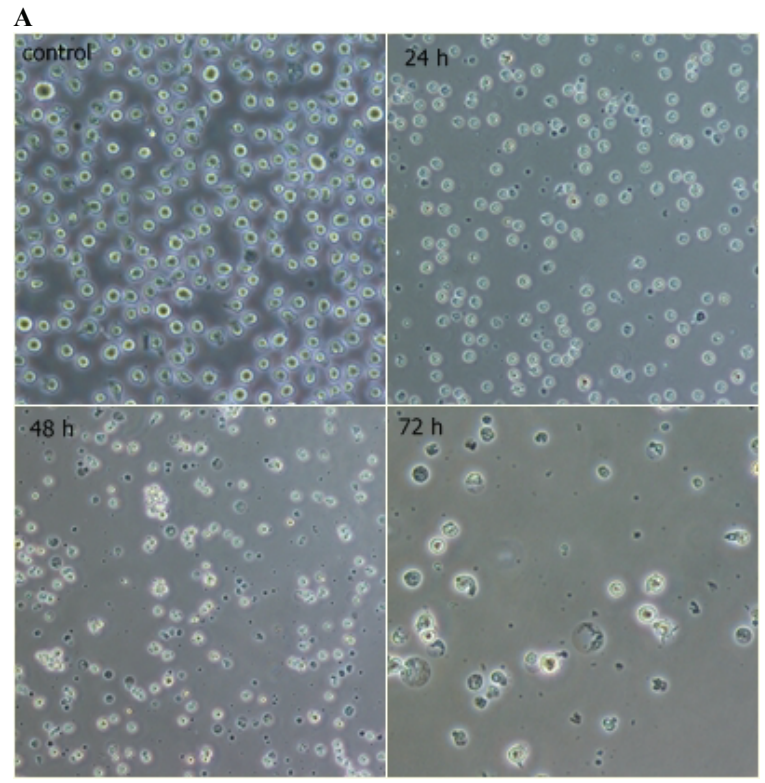

B

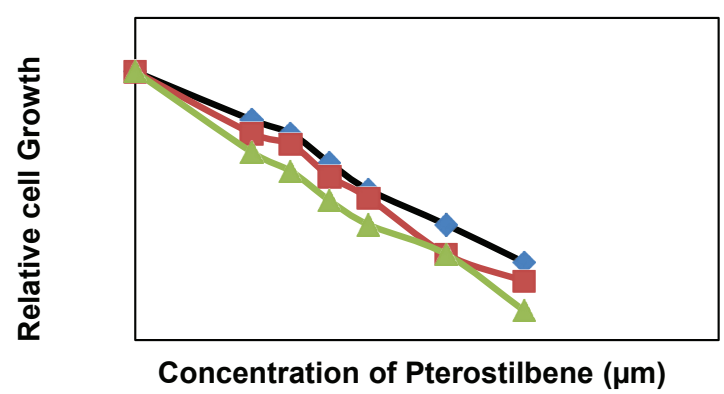

Fig. 1: Effect of pterostilbene on Jurkat cell viability

A) Cells incubated with $60 \mu \mathrm{M}$ concentration of PT over a period of 24,48 and $72 \mathrm{~h}$. Controls are the cells incubated with media after $72 \mathrm{~h}$ incubation. The antiproliferative effect of PT on Jurkat cells is time-dependent. B) Cells incubated with different concentrations of PT for 24, 48 and $72 \mathrm{~h}$ and MTS assay was performed to detect the viable cells. Cell viability decreases in a concentration-dependent manner. All experiments were done in triplicate. PT is pterostilbene $(\mu \mathrm{M})$. $(-\bullet-) 24 \mathrm{~h}$; (一匹) $48 \mathrm{~h}$; (- $\triangle-) 72 \mathrm{~h}$

March-April 2019 of $72 \mathrm{~h}$ incubation time with the same concentrations as it was $11.21 \pm 2.65 \%$ at $100 \mu \mathrm{M}$. As fig. 1 shows, PT decreased cell viability in a time and dose-dependent manner.

Jurkat cells were seeded in a concentration of $1 \times 10^{4}$ cells per well in a 96 well plate and incubated with different concentration (0.01-1 IU/ml) of L-ASP alone or in combination with different concentrations of PT. Cell viability declined slightly after $24 \mathrm{~h}$ incubation with L-ASP (EC50 of $1.86 \pm 0.23$ ), but fell to less than $40 \%$ after $72 \mathrm{~h}$ incubation with $0.7 \mathrm{IU} / \mathrm{ml}$ concentration of the drug. L-ASP declined cell viability to $71.12 \pm 2.08$, $52.34 \pm 3.06$ and $47.21 \pm 3.06 \%$ at the concentration of $0.1,0.5$ and $0.7 \mathrm{IU} / \mathrm{ml}$ with an EC50 of $0.66 \pm 0.08 \mathrm{IU} / \mathrm{ml}$ after $48 \mathrm{~h}$ incubation, respectively (fig. 2A). The viability decreased to $33.17 \pm 4.16$ and $28.12 \pm 4.0 \%$ when the cells were treated with a combination of $30 \mu \mathrm{m}$

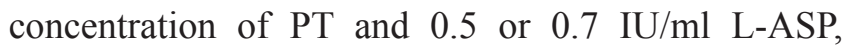
respectively. The cell viability declined to $55.14 \pm 4.36$, $30.32 \pm 3.06$ and $21.41 \pm 3.0 \%$ using a combination of $50 \mu \mathrm{m}$ concentrations of PT and $0.1,0.5$ and $0.7 \mathrm{IU} / \mathrm{ml} \mathrm{L}-\mathrm{ASP}$, respectively. Viable cells reduced to $35.61 \pm 6.01,25.23 \pm 3.0$ and $18.52 \pm 2.01 \%$ in the presence of $0.1,0.5$ and $0.7 \mathrm{IU} / \mathrm{ml} \mathrm{L}-\mathrm{ASP}$, respectively, when used with $70 \mu \mathrm{m}$ concentration of PT $(\mathrm{p}<0.05$, fig. 2B).

Cell apoptosis was analysed after treatment with different concentration of PT. Forty eight hours after incubation with the drug, percent apoptotic cells was determined by flowcytometry considering the annexin V FTIC positive cells. Higher apoptosis was observed at higher concentration of PT. Fig. 3A demonstrates an example of apoptosis at 40 and $60 \mu \mathrm{M}$ concentration of PT compared to control. As shown in fig. $3 \mathrm{~B}, \mathrm{PT}$ at the concentrations of 40,60 and $80 \mu \mathrm{M}$ induced $27.17 \pm 6.56,49.41 \pm 7.02$ and $60.71 \pm$ $8.62 \%$ cell apoptosis, respectively. There was a significant difference between control and PT at $80 \mu \mathrm{M}$.

Apoptosis was analysed in the presence of L-ASP alone or in combination with PT. Cells were incubated with different concentrations of L-ASP alone or in combination with $60 \mu \mathrm{m}$ concentration of PT for $48 \mathrm{~h}$. As fig. 4A illustrates, the apoptosis was $22.75 \pm 5.31$ and $57.49 \pm 9.70 \%$ after treatment with $0.5 \mathrm{IU} / \mathrm{ml} \mathrm{L}-\mathrm{ASP}$ alone or in combination with $60 \mu \mathrm{m}$ PT $(\mathrm{p}<0.05)$, respectively. The apoptosis increased to $34.05 \pm 9.08$ and $69.41 \pm 9.59 \%$ in the presence of $0.7 \mathrm{IU} / \mathrm{ml} \mathrm{L-ASP}$ alone and in combination with $60 \mu \mathrm{m}$ PT, respectively 
compared to $8.32 \%$ in control $(\mathrm{p}<0.05)$. As fig. 4B demonstrates, the combination induced more apoptosis than L-ASP or PT alone.

Intracellular active caspase 3 was measured by flowcytometry after permeabilization and fixation of the cells and incubation with anticaspase 3 PIconjugated monoclonal antibody. After $48 \mathrm{~h}$ incubation with different concentration of PT, the percentage of positive cells was detected by flowcytometry. The mean value of positive cells in three experiments was $18.37 \pm 1.01,25.38 \pm 3.06$ and $40.85 \pm 1.25 \%$ in the presence of 40, 60 and $80 \mu \mathrm{m}$ concentrations of PT, respectively compared to $7.32 \pm 2.01 \%$. Although the ratio of positive cells increased in all concentrations,
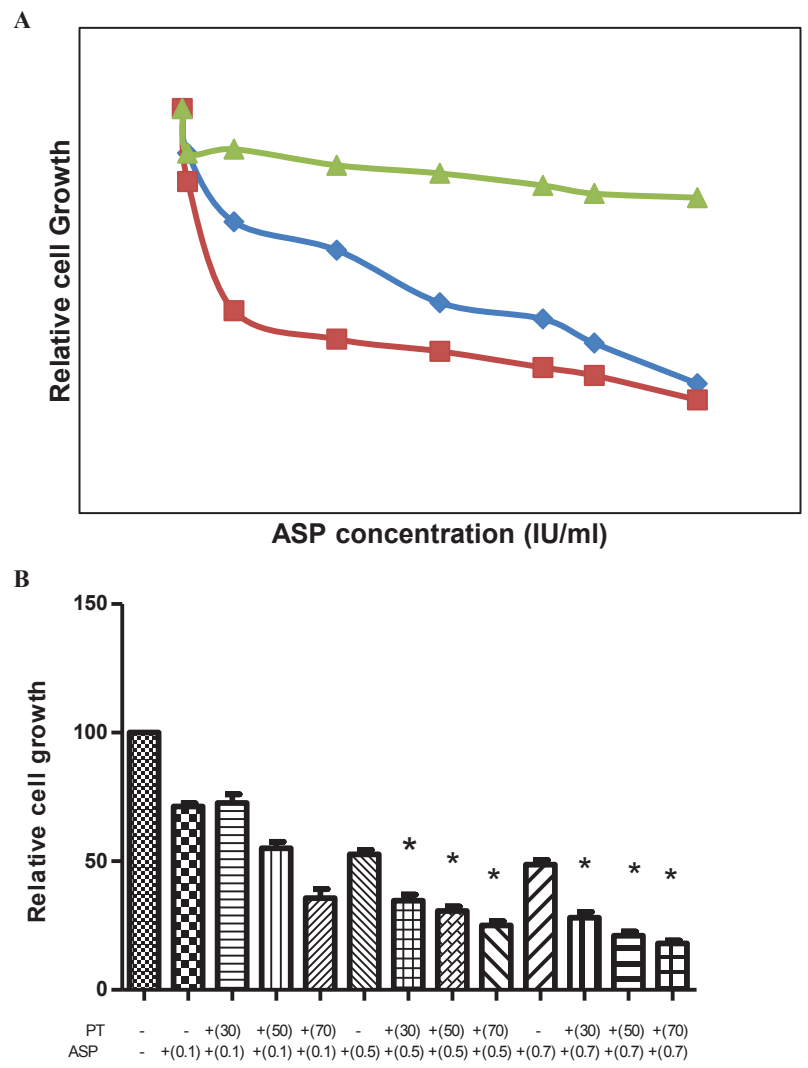

Fig. 2: Cell viability in the presence of $L$-asparaginase alone or in combination with PT

A) Cells incubated with different concentrations of L-ASP for 24, 48 and $72 \mathrm{~h}$ and MTS assay was performed to detect the viable cells. Cell viability decreased after 48 and $72 \mathrm{~h}$ with a concentration-dependent manner. All experiments were done in triplicate. B) Cell viability was detected after $48 \mathrm{~h}$ incubation with different concentrations of L-ASP alone or in combination with different concentrations of PT. Each experiment was performed in triplicates or more and cell viability compared to control. Cell viability decreased to a significant level when a concentration of 0.5 and $0.7 \mathrm{IU} / \mathrm{ml}$ of $\mathrm{L}$-asparaginase was combined with 30, 50 and $70 \mu \mathrm{M}$ concentration of PT. KruskalWallis multiple comparison and Dunn's test, ("shows significant difference compared to control and indicates $p<0.05)$. ASP is asparaginase $(\mathrm{IU} / \mathrm{ml}), \mathrm{PT}$ is pterostilbene $(\mu \mathrm{M}) .(-\downarrow) 24 \mathrm{~h}$; $(-\square-) 48 \mathrm{~h} ;(-\Delta-) 72 \mathrm{~h}$ there was more than two and three-fold increase at 40 and $60 \mu \mathrm{m}$ compared to control, the difference was significant only at the $80 \mu \mathrm{m}$ concentration (fig. 5).

The treatment approaches of ALL were developed in the last decade, however common chemotherapy has failed in some patients. The development of therapies that could improve the quality of life without compromising survival is promising. In the present study we represented the enhancement of the effect of L-ASP in combination with PT on cell viability and apoptosis of a lymphoblastic leukaemia cell line. Different studies have reported anticancer activity, induction of apoptosis and inhibition of proliferation of PT on some tumor cell lines. Here we demonstrated the effect of PT, on inhibiting cell proliferation, inducing apoptosis and increasing caspase 3 in Jurkat cell line. The drug also increased the antiproliferative and apoptotic effect of L-ASP.

The current data demonstrated that PT decreased viability of Jurkat cells in a time- and dose-dependent manner and viability fell to around $50 \%$ at $61 \mu \mathrm{m}$ concentration after $48 \mathrm{~h}$ incubation. Different studies have demonstrated that the EC50 of PT is variable and dependent to the cell line $\mathrm{e}^{[16,24,25]}$. Tolomeo et al. studied PT effect on seven cell line including human myeloid cell line and drug resistant myeloid cells. They concluded that PT had dose-dependent inhibitory effect on cell growth ${ }^{[16]}$.

PT also increased antiproliferative effect of L-ASP in our study. L-ASP is a part of combination chemotherapy for ALL and some of the solid tumours and has demonstrated antitumor activity on leukemic cell lines including Jurkat cells. Abakumova et al. demonstrated the cytotoxicity of ASP on different cell lines at the concentration of $0.02-10 \mathrm{IU} / \mathrm{ml}$ including Jurkat cells ${ }^{[26]}$. Apparently different cell lines have different sensitivity to L-ASP ${ }^{[27]}$. In the present study dose-dependency of this effect was demonstrated as maximal inhibition of cell growth was at the highest concentration of $1 \mathrm{IU} / \mathrm{ml}$ used. The important finding was the enhancement of this antiproliferative effect in the presence of PT. In fact the combination of $0.7 \mathrm{IU} / \mathrm{ml}$ of L-ASP with $70 \mu \mathrm{m}$ of PT led to $82 \%$ growth inhibition. As more intensive treatment with conventional combination chemotherapy can lead to increased side effects, the addition of PT to those combinations could improve the outcome. The additive or synergistic antiproliferative effect of a plant-derived constituent with another ALLchemotherapy agent, doxorubicin, was reported on 
A

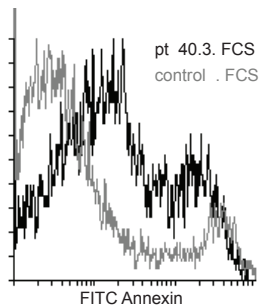

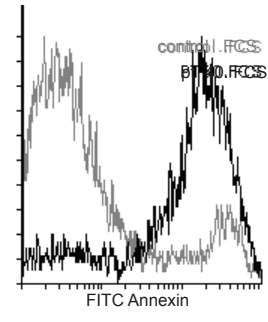

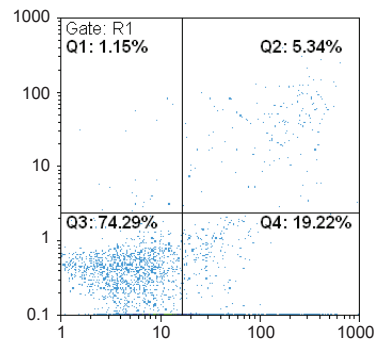

Apoptosis vs. necrosis

B

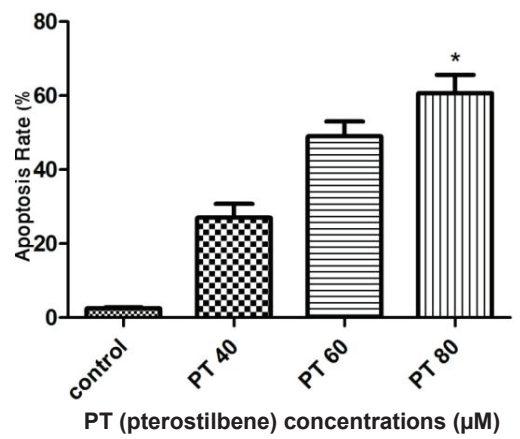

Fig. 3: Analysis of apoptosis

Cells were incubated with different concentration of PT or media for $48 \mathrm{~h}$, then stained for apoptosis and analysed by flowcytometry. The annexin $\mathrm{V}$ positive cells were considered as apoptotic cells and the treated cells were compared to control. A) A representative sample of flowcytometric analysis: apoptosis in (a) 40 and (b) $60 \mu \mathrm{M}$ concentration (black) was compared to control (grey). B) The apoptosis was $27.17 \pm 6.56,49.41 \pm 7$ and $60.71 \pm 8.62 \%$ at the concentrations of 40,60 and $80 \mu \mathrm{M}$, respectively compared to 4.8.01 $\pm 1.12 \%$ in control. Each experiment was performed in triplicate. * $p<0.05$ compared to control
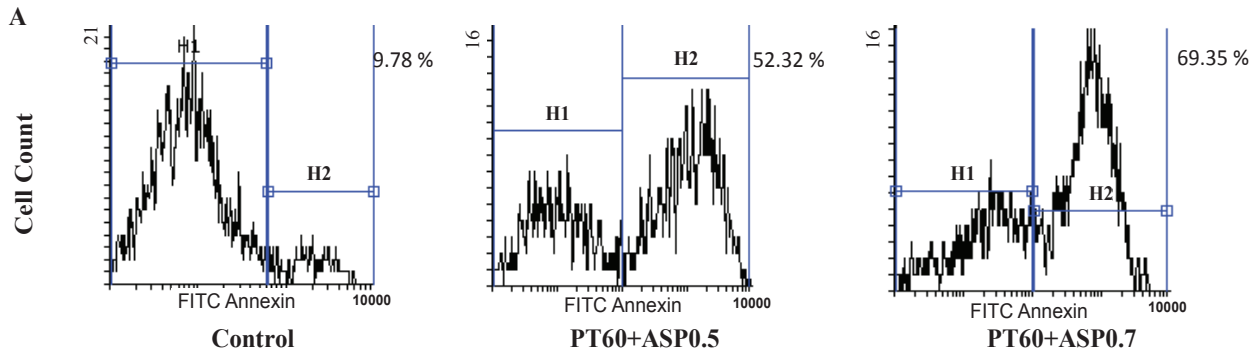

B

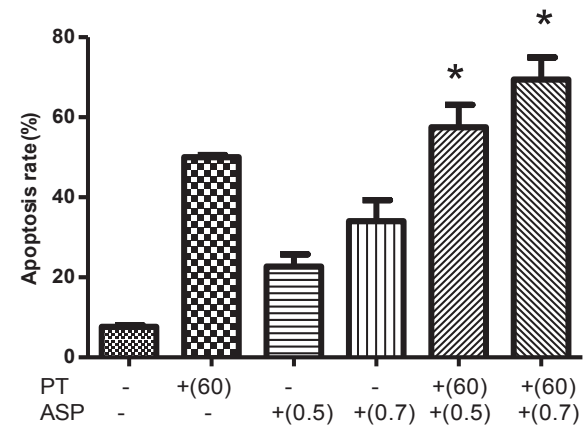

Fig. 4: Apoptosis in the presence of ASP or in combination with PT

Jurkat cells were treated with L-ASP alone or in combination with $60 \mu \mathrm{M}$ concentration of PT for $48 \mathrm{~h}$, then stained and analysed by flowcytometry. A) A representative sample of apoptosis was induced by 0.5 and $0.7 \mathrm{IU} / \mathrm{ml} \mathrm{L}-\mathrm{ASP}$ in combination with $60 \mu \mathrm{M}$ of PT. B) Apoptosis level in the presence of ASP alone and in combination with $60 \mu \mathrm{M}$ concentration of PT. Untreated cells served as control. A significant difference was observed between control and a combination of 0.5 or 0.7 IU/ml L-ASP with $60 \mu \mathrm{M}$ PT. Kruskal-Wallis multiple comparison and Dunn's test, *significant compared to control at $\mathbf{p}<0.05$. Pterostilbene is in $\mu$ M, ASP is Asparaginase concentration in IU/ml 
A

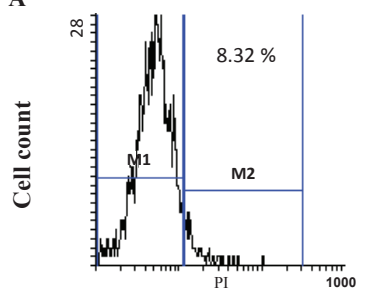

0

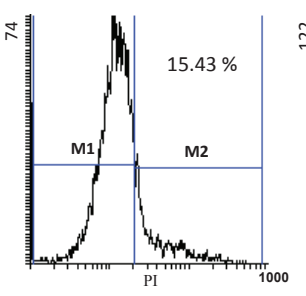

40

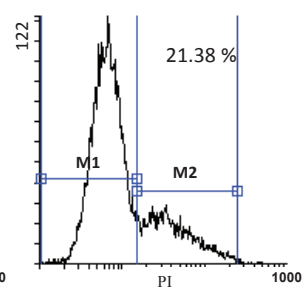

60

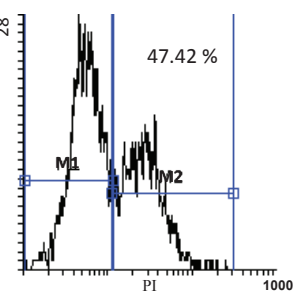

80

Concentration of PT $(\mu \mathrm{m})$

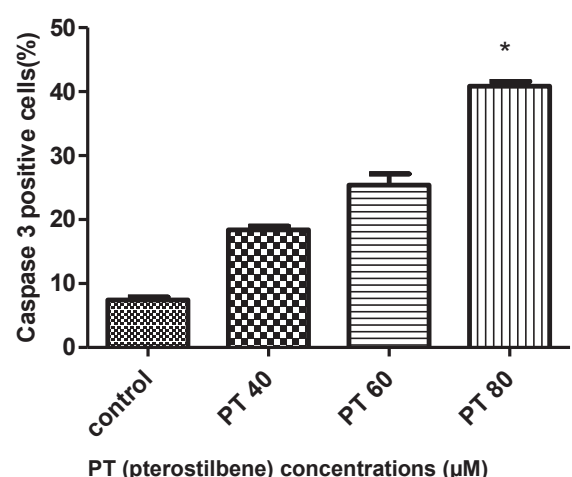

Fig. 5: Alteration of the level of caspase 3 positive cells in the presence of PT

Cells treated with different concentrations of PT or incubated with media alone as control. A) A representative sample of flowcytometric analysis of intracellular caspase 3 positive cells treated with $0,40,60$, and $80 \mu \mathrm{M}$ concentration of PT. B) The mean frequency of caspase 3 positive cells were $18.37 \pm 1.01,25.38 \pm 3.06$, and $40.85 \pm 1.28 \%$ at concentrations of 40,60 and $80 \mu \mathrm{M}$, respectively, compared to $7.32 \pm \mathbf{2 . 0 1} \%$ in control. The experiments were performed in triplicate. *p<0.05 compared to control

lymphoblastic leukaemia cells ${ }^{[28]}$. The present work also demonstrated the dose-dependency of apoptosis upon treatment with PT as such effect with other plantderived compounds, epigallocatechin-3-gallate and gallic acid in lymphoblastic cell line was previously reported ${ }^{[29,30]}$.

To investigate the mechanism of antitumor effect of PT, cell apoptosis was investigated using flowcytometry. Apoptosis is a mechanism, which an organism applies to delete harmed or unnecessary cells. In the process of cancer development, existing mutations allow cells to avoid apoptosis. Therefore, induction of apoptosis in pro-cancer and cancer cells could be an approach to prevention and treatment ${ }^{[31]}$. In the present investigation, the concentration of PT associated with highest apoptosis rate by flowcytometric analysis caused remarkable decrease in cell viability in cell proliferation assay as well. An increase in caspase 3 positive cells to a significant level at $80 \mu \mathrm{M}$ concentration of PT was also observed. This finding in Jurkat cells is in accordance with other cell lines.

These results demonstrated that apoptosis increased in the presence of PT and PT enhanced L-ASP-induced cell apoptosis. The induction of apoptosis by L-ASP is controversial. Holleman et al. have already reported a significant inverse correlation between cellular resistance to L-ASP and the percentage of cells with phosphatidyl serine externalization in children with $\mathrm{ALL}^{[32]}$. The inhibitory effect on cancer cell growth is mediated by the modulation of genes involved in cell cycle, apoptosis and metastasis ${ }^{[33]}$. Abakumova et al. demonstrated that treatment with L-ASP for $72 \mathrm{~h}$ did not change cell cycle distribution and did not increase the number of apoptotic cells. A combination with doxorubicin increased apoptosis of Jurkat cells up to $40 \%$. They concluded that apoptosis might not be the main reason for tumor cell death after treatment with L-ASP ${ }^{[26]}$. This interpretation could explain findings of this investigation in the presence of a combination of PT and L-ASP, as significant increase in the apoptosis was observed compared to that with L-ASP alone. L-ASP induced extracellular asparagine hydrolysis, stopped asparagine-dependent proteins, prevented DNA synthesis and decreased leukemic cell proliferation ${ }^{[27]}$. It was reported that asparagine deficiency stopped cells dividing rather than killing them ${ }^{[26]}$. Some cell lines increase asparagine synthesis in response to amino acid deprivation ${ }^{[27]}$. It appeared that similar effect was encountered in the current experiments 
with Jurkat cells, as no remarkable apoptosis was noticed with L-ASP alone. This finding is compatible with some of the previous studies where ASP did not induce remarkable apoptosis in Jurkat cell line. This phenomenon might be related to the high expression of antiapoptotic proteins of BCL2 family in these cells ${ }^{[34]}$. Resveratrol was shown to be involved in the type I and type II pathways of apoptosis in human cancer cells $^{[35]}$ and to have cytotoxic effect on tumor cells but not normal tissue ${ }^{[36]}$. Schneider et al. demonstrated the inhibitory effect of PT on melanoma cell line, which was associated with an increase in caspase activity ${ }^{[37]}$. Previous studies have also reported the effect of PT on apoptosis through caspase cascade activation in pancreatic cancer ${ }^{[20]}$.

PT was involved in inducing depolarization of mitochondrial membrane in breast cancer cell line and an increase in caspase 3/7. PT enhanced mitochondrial pro-apoptotic Bax and decreased mitochondrial antiapoptotic Bcl-2 $2^{[38]}$. Current study demonstrated that the induction of apoptosis was not considerable with L-ASP, but PT enhanced this apoptotic effect up to a significant level. Wang et al. found the potentiation of antitumor activity of ASP by curcumin ${ }^{[39]}$, which demonstrated the effect of combination treatment and is in accordance with our findings on proliferation assay and apoptosis.

Overall, PT might be a potential anticancer compound against lymphoblastic leukaemia and increase the effect of ASP, however these effects on ALL patients' lymphoblasts need to be investigated. As PT, a resveratrol analogue, can have cytotoxic effect on tumor cells but not normal tissue, it can be considered as a potential choice of ALL chemotherapy. The study of the mechanism of PT-induced apoptosis and signalling pathways in lymphoblastic cell lines besides in vivo studies of experimental models could be a step toward targeted therapy.

\section{Acknowledgements:}

The authors would like to thanks the Deputy of Research and Technology of Shahrekord University of Medical sciences for financial support, with the grant number 1316. Authors also thank Medical Plants Research Center of this university. The results described in this paper were part of the first author's thesis.

\section{Conflict of interest:}

Authors declared that there is no conflict of interest.

\section{REFERENCES}

1. Kim AS, Eastmond DA, Preston RJ. Childhood acute lymphocytic leukemia and perspectives on risk assessment of early-life stage exposures. Mutat Res 2006;613(2):138-60.

2. Pui C-H, Evans WE. Treatment of acute lymphoblastic leukemia. N Engl J Med 2006;354(2):166-78.

3. Pieters R, Klumper E, Kaspers GJ, Veerman AJ. Everything you always wanted to know about cellular drug resistance in childhood acute lymphoblastic leukemia. Crit Rev Oncol Hematol 1997;25(1):11-26.

4. Holleman A, den Boer ML, Kazemier KM, Beverloo HB, von Bergh AR, Janka-Schaub GE, et al. Decreased PARP and procaspase-2 protein levels are associated with cellular drug resistance in childhood acute lymphoblastic leukemia. Blood 2005;106(5):1817-23.

5. Taylor CW, Dorr RT, Fanta P, Hersh EM, Salmon SE. A phase I and pharmacodynamic evaluation of polyethylene glycolconjugated L-asparaginase in patients with advanced solid tumors. Cancer Chemother Pharmacol 2001;47(1):83-8.

6. Muller HJ, Boos J. Use of L-asparaginase in childhood ALL. Crit Rev Oncol Hematol 1998;28(2):97-113.

7. Gong H, Zolzer F, von Recklinghausen G, Havers W, Schweigerer L. Arginine deiminase inhibits proliferation of human leukemia cells more potently than asparaginase by inducing cell cycle arrest and apoptosis. Leukemia 2000;14(5):826-9.

8. Kawahara Y, Morimoto A, Hayase T, Kashii Y, Fukuda T, Momoi MY. Monitoring of anti-L-asparaginase antibody and L-asparaginase activity levels in a pediatric patient with acute lymphoblastic leukemia and hypersensitivity to native Escherichia coli L-asparaginase during desensitization courses. J Pediatr Hematol Oncol 2014;36(2):e91-3.

9. Panosyan EH, Seibel NL, Martin-Aragon S, Gaynon PS, Avramis IA, Sather $\mathrm{H}$, et al. Asparaginase antibody and asparaginase activity in children with higher-risk acute lymphoblastic leukemia: Children's Cancer Group Study CCG-1961. J Pediatr Hematol Oncol 2004;26(4):217-26.

10. Burns J, Yokota T, Ashihara H, Lean ME, Crozier A. Plant foods and herbal sources of resveratrol. J Agric Food Chem 2002;50(11):3337-40.

11. McCormack D, McFadden D. Pterostilbene and cancer: current review. J Surg Res 2012;173(2):e53-e61.

12. Lin HS, Yue BD, Ho PC. Determination of pterostilbene in rat plasma by a simple HPLC-UV method and its application in pre-clinical pharmacokinetic study. Biomed Chromatogr 2009;23(12):1308-15.

13. Remsberg CM, Yanez JA, Roupe KA, Davies NM. Highperformance liquid chromatographic analysis of pterostilbene in biological fluids using fluorescence detection. J Pharm Biomed Anal 2007;43(1):250-4.

14. Ferrer P, Asensi M, Segarra R, Ortega A, Benlloch M, Obrador $\mathrm{E}$, et al. Association between pterostilbene and quercetin inhibits metastatic activity of B16 melanoma. Neoplasia 2005;7(1):37-47.

15. Suh N, Paul S, Hao X, Simi B, Xiao H, Rimando AM, et al. Pterostilbene, an active constituent of blueberries, suppresses aberrant crypt foci formation in the azoxymethaneinduced colon carcinogenesis model in rats. Clin Cancer Res 2007;13(1):350-5.

16. Tolomeo M, Grimaudo S, Cristina AD, Roberti M, Pizzirani $\mathrm{D}$, Meli $\mathrm{M}$, et al. Pterostilbene and 3'-hydroxypterostilbene are effective apoptosis-inducing agents in MDR and BCR- 
ABL-expressing leukemia cells. Int J Biochem Cell Biol 2005;37(8):1709-26.

17. Alosi JA, McDonald DE, Schneider JS, Privette AR, McFadden DW. Pterostilbene Inhibits Breast Cancer in vitro Through Mitochondrial Depolarization and Induction of CaspaseDependent Apoptosis. J Surg Res 2010;161(2):195-201.

18. Chen RJ, Tsai SJ, Ho CT, Pan MH, Ho YS, Wu CH, et al. Chemopreventive effects of pterostilbene on urethaneinduced lung carcinogenesis in mice via the inhibition of EGFR-mediated pathways and the induction of apoptosis and autophagy. J Agric Food Chem 2012;60(46):11533-41.

19. Hasiah AH, Ghazali AR, Weber JF, Velu S, Thomas NF, Inayat Hussain SH. Cytotoxic and antioxidant effects of methoxylated stilbene analogues on HepG2 hepatoma and Chang liver cells: Implications for structure activity relationship. Hum Exp Toxicol 2011;30(2):138-44.

20. Mannal PW, Alosi JA, Schneider JG, McDonald DE, McFadden DW. Pterostilbene inhibits pancreatic cancer in vitro. J Gastrointest Surg 2010;14(5):873-9.

21. McCormack DE, Mannal P, McDonald D, Tighe S, Hanson J, McFadden D. Genomic analysis of pterostilbene predicts its antiproliferative effects against pancreatic cancer in vitro and in vivo. J Gastrointest Surg 2012;16(6):1136-43.

22. Pan MH, Chang YH, Badmaev V, Nagabhushanam K, Ho CT. Pterostilbene induces apoptosis and cell cycle arrest in human gastric carcinoma cells. J Agric Food Chem 2007;55(19):777785.

23. Schneider JG, Alosi JA, McDonald DE, McFadden DW. Pterostilbene inhibits lung cancer through induction of apoptosis. J Surg Res 2010;161(1):18-22.

24. Rahimnejad T, Shirzad H, RafieianKoupaie M, Safdarian V, Asgharian-Dehkordi N, Pourgheysari B. Effect of Pterostilbene on cellular proliferation and induction of apoptosis in lymphoblastic leukemia cell line. J Babol Univ Med Sci 2014;16(12):32-8.

25. Mena S, Rodríguez ML, Ponsoda X, Estrela JM, Jäättela M, Ortega AL. Pterostilbene-induced tumor cytotoxicity: a lysosomal membrane permeabilization-dependent mechanism. PloS One 2012;7(9):e44524.

26. Abakumova OY, Podobed O, Karalkin P, Kondakova L, Sokolov N. Antitumor activity of L-asparaginase from Erwinia carotovora against different human and animal leukemic and solid tumor cell lines. Biomed Chem 2012;6(4):307-16.

27. Estlin EJ, Ronghe M, Burke GA, Yule SM. The clinical and cellular pharmacology of vincristine, corticosteroids, L-asparaginase, anthracyclines and cyclophosphamide in relation to childhood acute lymphoblastic leukaemia. Br J Haematol 2000;110(4):780-90.
28. Soltani A, Pourgheysari B, Shirzad H, Sourani Z. Antiproliferative and Apoptosis-Inducing Activities of Thymoquinone in Lymphoblastic Leukemia Cell Line. Indian J Hematol Blood Transfus 2017;33(4):516-24.

29. Ghasemi-Pirbaluti M, Pourgheysari B, Shirzad H, Beshkar P, Pirayesh A. Effect of Epigallocatechin-3-gallate (EGCG) on cell proliferation inhibition and apoptosis induction in lymphoblastic leukemia cell line. J Herbmed Pharmacol 2015;4(2):65-8.

30. Sourani Z, Pourgheysari B, Beshkar P, Shirzad H, Shirzad M. Gallic Acid Inhibits Proliferation and Induces Apoptosis in Lymphoblastic Leukemia Cell Line (C121). Iran J Med Sci 2016;41(6):525-30.

31. Fesik SW. Promoting apoptosis as a strategy for cancer drug discovery. Nat Rev Cancer 2005;5(11):876-85.

32. Holleman A, den Boer ML, Kazemier KM, Janka-Schaub GE, Pieters R. Resistance to different classes of drugs is associated with impaired apoptosis in childhood acute lymphoblastic leukemia. Blood 2003;102(13):4541-6.

33. Domenech C, Thomas X, Chabaud S, Baruchel A, Gueyffier F, Mazingue F, et al. 1-asparaginase loaded red blood cells in refractory or relapsing acute lymphoblastic leukaemia in children and adults: results of the GRASPALL 2005-01 randomized trial. Br J Haematol 2011;153(1):58-65.

34. Laukens B, Jennewein C, Schenk B, Vanlangenakker N, Schier A, Cristofanon S, et al. Smac mimetic bypasses apoptosis resistance in FADD- or caspase-8-deficient cells by priming for tumor necrosis factor alpha-induced necroptosis. Neoplasia 2011;13(10):971-9.

35. Aggarwal BB, Bhardwaj A, Aggarwal RS, Seeram NP, Shishodia S, Takada Y. Role of resveratrol in prevention and therapy of cancer: preclinical and clinical studies. Anticancer Res 2004;24(5A):2783-840.

36. Athar M, Back JH, Tang X, Kim KH, Kopelovich L, Bickers $\mathrm{DR}$, et al. Resveratrol: a review of preclinical studies for human cancer prevention. Toxicol Appl Pharmacol 2007;224(3):274-83.

37. Schneider JG, Alosi JA, McDonald DE, McFadden DW. Effects of pterostilbene on melanoma alone and in synergy with inositol hexaphosphate. Am J Surg 2009;198(5):679-84.

38. McCormack D, Schneider J, McDonald D, McFadden D. The antiproliferative effects of pterostilbene on breast cancer in vitro are via inhibition of constitutive and leptin-induced Janus kinase/signal transducer and activator of transcription activation. Am J Surg 2011;202(5):541-4.

39. Wang H, Geng QR, Wang L, Lu Y. Curcumin potentiates antitumor activity of L-asparaginase via inhibition of the AKT signaling pathway in acute lymphoblastic leukemia. Leuk Lymphoma 2012;53(7):1376-82. 